\title{
AN EXPLORATORY CASE STUDY ANALYSIS OF CONTEMPORARY MARKETING PRACTICES
}

\author{
Roger Palmer and Hugh Wilson*
}

Published in Journal of Strategic Marketing (2009), 17(2), 169-187

Final Word version as provided for typesetting

Prof Roger Palmer (author for correspondence) Prof Hugh Wilson

Henley Business School

Greenlands

Henley-on-Thames

RG9 3AU

UK

Tel: $+44(0) 1491571454$

Fax: +44(0)1491571635
*Cranfield School of Management

Cranfield

Bedford

MK43 0AL

UK

Tel: $+44(0) 1234751122$

Fax: +44 1234751806

roger.palmer@henley.reading.ac.uk

hugh.wilson@cranfield.ac.uk

Roger Palmer is Professor of Marketing and Management at Henley Business School. Hugh Wilson is Professor of Strategic Marketing at Cranfield School of Management. 


\section{AN EXPLORATORY CASE STUDY ANALYSIS OF CONTEMPORARY MARKETING PRACTICES}

\section{Biographies}

Roger Palmer is Professor of Marketing and Management at Henley Business School, University of Reading, UK and is also Head of the School of Management. He has substantial industrial experience including marketing director of a large manufacturing company and CEO/General Manager of the UK/Ireland subsidiary of an American multi-national. He teaches and consults around the world, and is a Visiting Professor at the Brisbane Graduate School of Business and at the University of Auckland Business School. His research interests include relationship and value management, technology and product development, and contemporary marketing practice. He has published widely in both academic and practitioner journals.

Hugh Wilson is Professor of Strategic Marketing and Director of the Customer Management Forum at Cranfield School of Management, UK. After a mathematics degree at Oxford University and a postgraduate computer science degree at Cambridge University, he spent thirteen years in the computing industry, before gaining a prize-winning $\mathrm{PhD}$ from Cranfield University. He has published in British Journal of Management, Industrial Marketing Management, European Journal of Information Systems, Journal of Strategic Information Systems, Journal of Marketing Management and European Journal of Marketing amongst other journals. His books include "The Multichannel Challenge" (Butterworth Heinemann 2008, with Rod Street and Lindsay Bruce). 


\title{
AN EXPLORATORY CASE STUDY ANALYSIS OF CONTEMPORARY MARKETING PRACTICES
}

\begin{abstract}
The Contemporary Marketing Practice (CMP) research tradition has formulated and investigated a set of different marketing practices or archetypes ranging from transactional to relationship and network approaches. We identify gaps in previous research, and report on a case study in the house-building industry which begins to fill these gaps. Specifically, we propose some amendments to the definition and detail of the marketing practices, arguing for example that e-marketing does not exist as a separate practice but rather that marketing practices are independent of the specific media and technology used at the customer interface. We also explore drivers and enabling factors of transitions between practices. Further case study research is called for in this domain.
\end{abstract}

\section{KEYWORDS}

Relationship marketing, network marketing, marketing practice, interactive marketing, case study

\section{INTRODUCTION}

There have long been calls for more research into marketing practice, into what marketers actually do and the implementation of marketing (Bonoma, 1985; Webster, 1992; Brownlie and Saren, 1997; Brownlie et al., 1999, Hunt, 1994). The CMP (Contemporary Marketing Practice) programme of research provides a framework within which this can be pursued.

The CMP programme, founded at the University of Auckland, has developed into a globally coordinated study conducted by a network of marketing academics at various universities. The programme has two primary objectives:

- $\quad$ To profile the contemporary marketing practices of different types of firms competing in different market and sector contexts, in an international forum

- To develop an understanding of how firms relate to their markets in a manner that integrates both traditional and more modern views of marketing, and incorporates an understanding of both the antecedents and consequences of different practices.

The CMP programme has demonstrated reasonably consistent results in terms of the marketing practices identified. We argue, though, that this early questionnaire-based work needs supplementing by in-depth case studies to enrich and expand the understanding gained to date. We report and discuss a first such case study, conducted in the UK house-building industry.

\section{THE CMP PROGRAMME}

Whilst relationship marketing presents elegant suggestions and possible explanations as to how firms behave, the relative paucity of empirical work leaves the field open to criticism. In particular relationship marketing has been criticised for being overly conceptual and lacking in testable theory and output (Sheth 2000). To be fair, the underlying arguments in favour of an increased emphasis on customer retention have been underpinned by numerous studies, such as: the influential study by 
Reichheld and Sasser (1990) which showed the large impact on profitability of small increases in customer retention rates; data on the low cost of better retention as compared with better acquisition (Blattberg and Deighton 1996); and evidence for the increasing profitability of customers the longer the relationship lasts (Reichheld 1996). A holistic view of what relationship marketing might look like in practice, or of the extent to which it is indeed practiced, is difficult to find, however. Here, the work of Brodie et al (1997) was an important contribution as it made tangible and therefore researchable the notion of relationship marketing as a marketing practice.

There is no clear consensus as to what constitutes relationship marketing, but it is rather more disparate than this all-encompassing term would imply. The concept is derived from a range of business areas and theoretical bases. The early work of the CMP group involved a thorough literature review that drew together these various strands (Coviello et al 1997). The group's work similarly synthesised literature on other marketing practices such as the transactional approach, concluding that greater insight, understanding and explanation of what is actually happening in marketing can be gained by the delineation of four dominant marketing archetypes or practices, spanning transactional to relational marketing (Brookes and Palmer, 2004). The marketing archetypes are labelled transactional, database, interaction and network marketing. A hypothesised fifth practice of e-marketing has been proposed by some researchers on the basis of further work (Coviello et al 2001). These practices or archetypes are defined in Table 4 (see 'Previous definition' column), and the major dimensions of marketing practice for each archetype are summarised in the theoretical framework of Table 1 (from Coviello et al 2002).

This framework formed the basis from which a questionnaire was developed as the primary means to date of data gathering, which has subsequently been used around the world. The findings (Coviello et al 2002) challenge some accepted understandings of marketing, such as the traditional assumption that B2B marketing is more 'relational' than B2C marketing. In practice, each of the marketing archetypes is well-represented in both the B2B and B2C domains, though there is a tendency on average for consumer companies to relate to their markets in a more transactional manner than do business-to-business firms. The differences between products and services marketing are similarly subtle. Goods companies tend to be more transactional than services companies, but again this difference is far from universal. Furthermore, there are no significant differences between goods and services firms in the extent to which they engage in database marketing, interaction marketing or network marketing behaviour. This suggests that broad generalisations about the difference between B2B and B2C marketing, or marketing of goods versus services, are misleading, and that a debate around the different archetypes, or clusters of archetype combinations, might be more fruitful: "The diversity of marketing practice is self evident, yet exploration of its nature and archetypal order is muted within the marketing academy" (Murray et al 2002).

Another finding from the survey work is that organisations do not tend to adopt a single marketing practice or archetype wholeheartedly; rather, several practices are represented within the 
firm in differing proportions. By the use of clustering techniques it is possible to identify those hybrids that are most common. Coviello (2002), for example, identified three clusters: a primarily transactional cluster, a primarily 'relational' cluster with high scores for interaction marketing and network marketing; and a hybrid transactional/relational cluster, with high scores for all four archetypes.

The findings of CMP researchers, then, have built to a reasonably consistent pattern (Brookes and Palmer 2004). There are weaknesses, however, in the survey approach which has been used to date, some of which are evident in the survey data itself. Referring to Table 1 specifically, whilst Coviello et al (2002) were able to construct multi-item scales for the presence of each archetype or practice in a firm based on this table, the reliability of these scales as measured by Cronbach's alpha was marginal (.62 for transaction marketing, 0.62 for database marketing, 0.71 for interaction marketing and 0.77 for network marketing), and even this reliability was only achieved by omitting several items from some of the scales. We have indicated these items by using italics in Table 1. If these items do not correlate strongly with the other items representing an archetype, this would seem to cast doubt on the correctness of these entries in the table. Qualitative research would appear a sensible means of investigating whether these entries - which were made primarily on the basis of a synthesis of previous conceptual literature - need modification in the light of the archetype as it is actually practiced.

A further issue to which qualitative research is well suited concerns transitions between archetypes. If companies decide to respond to calls to adopt relationship marketing approaches, for example, they clearly have a substantial change programme on their hands, even assuming they are clear on the desired end result. How organisations should manage such a transition is therefore a matter of as much importance to the practitioner as what the end-point should be. Yet we are aware of no specific research on this issue. While it would be unfair to regard the significant body of work on CRM implementation issues (Wilson et al 2002) as primarily about IT implementation, it tends to focus on specific IT-enabled CRM projects which typically address only certain aspects of the firm's relationship with its markets. It seems plausible that the broader challenge of making a transition in the firm's marketing practice may have different characteristics and be worthy of specific study.

Rather than continue to reinforce what is already known, then, we believe there is a need to complement the previous survey findings within the CMP tradition with qualitative data to improve the depth and richness of understanding around the concept of the archetypes. The case study reported here provides a first step towards this aim, and specifically towards the research objectives described in the next section, which we hope will be built on through further case studies by other researchers as well as by our continuing research programme. 


\section{RESEARCH OBJECTIVES AND METHOD}

We believe a research stream is needed to address the following objectives:

Objective 1 - To test and add depth to the CMP framework through an exploration of the detail of each marketing practice

Qualitative work is, we suggest, required to explore the detail of each practice in order to refine the theory summarised in Table 1. As well as providing a degree of methodological triangulation (Jick 1979), this needs specifically to focus on the areas of Table 1 where we have identified weaknesses based on previous data.

Objective 2 - To explore the drivers of transition between practices

Objective 3 - To explore factors that enable or inhibit the transition between practices

Marketing is a dynamic process embedded within the context of a wider social network. It is suggested that drivers such as new top management or a change in industry environment can lead to an attempted transition between marketing practices, such as the attempt to switch from a 'transactional' style to a 'database/interaction' hybrid in the case study below. We have suggested that such a transition poses significant managerial challenges. Qualitative work would, we believe, enable the nature of the drivers of such a transition, and the factors that inhibit or facilitate it, to be investigated, prior to any subsequent confirmatory further survey work.

As a first stage in a planned research stream to address these objectives, an in-depth case study has been conducted, which has generated some propositions for refinement in subsequent cases. This case was conducted as follows.

A subject company, Taylor Woodrow and specifically its Bryant house-building brand, was selected, on the basis that it appeared to exhibit aspects of more than one marketing practice, and that it had been attempting a transition in marketing practice, and research access was gained.

Data was gathered by means of semi-structured face to face interviews. The unit of analysis is the sales and marketing function, which in this organisation corresponded broadly to the department under the group sales and marketing director, though some activities were outsourced to an agency, the London-based Sledge. The interviewee set therefore included two agency staff as well as a 'vertical slice' of staff at each level of sales and marketing from board level downwards, so strategic and operational aspects of marketing practice could be studied. Nine interviews were conducted as follows:

- Commercial Director

- $\quad$ Sales and Marketing Director (3 interviews)

- Regional Sales and Marketing Director

- Marketing Executive

- $\quad$ Sales Executive 
- $\quad$ Agency's Creative Director

- $\quad$ Agency's Account Director for the Taylor Woodrow account.

All were tape-recorded and transcribed for analysis. In addition supporting documentation was gathered, together with observations and documentation gained from site visits.

Using the principles of case study analysis discussed by Miles and Huberman (1994), a case study description (summarised in the next section) was prepared based upon the transcriptions, and data was then tabulated to compare case data against the CMP framework. This was in order to establish the marketing practices of the subject company, to check for consistency of findings against the theoretical framework, and to establish the drivers and enablers of the attempted transition between marketing practices. In addition to a semi-structured interview schedule, all interviewees were shown Table 1 and a discussion ensued concerning the marketing approach of the case company. A simple diagnostic was used to develop a visual representation of the output of this discussion.

The next section summarises the case study's major themes in narrative form, before the following findings section provides a more formal analysis against the research objectives.

\section{CASE DESCRIPTION}

The case concerns Bryant Homes, the house building subsidiary of UK based Taylor Woodrow, better known for its involvement in major civil engineering and construction projects. Bryant Homes was purchased by Taylor Woodrow as part of a long term policy of moving into areas of higher added value and accessing the income stream of customers who not just purchase houses but then wish to decorate, furnish and maintain them. The senior management team have to manage the concurrent and sometimes conflicting requirements for house completions, sales and quality against the achievement of the longer term objectives of brand development, customer loyalty and widening of the opportunities to access income streams from customers - individuals who are making perhaps the largest single purchase of their lives.

\section{Background}

"I passionately believe that if we can develop a powerful relationship with even a brown fizzy drink, then we certainly can with the home in which we live our lives."

The logic of this agency executive is difficult to argue with. Yet although we might love our new home, we rarely feel as warmly about its builder. Marred by low production standards, unimaginative design and the lackadaisical attitude towards customers that stems from excess demand, we are more likely to view house-builders in the same category as insurance salesmen and car dealers. As one executive put it: 
"We're battling against the Barratt ${ }^{l}$ effect. The whole industry has been negatively branded."

Is this a problem when planning constraints mean that every house could be sold twice over? If shareholders want growth, yes. Obtaining good quality sites constrains the volume of production, while planning regulations which determine housing density constrain the product specification. Due to this perception Taylor Woodrow's Bryant housebuilding brand can rarely achieve high margins. Other than continuing taut cost control, this leaves differentiation through branding and added-value services as the available route to profit growth, in the view of Taylor Woodrow's Sales and Marketing Director:

"Some in the sector would argue that it's all about getting the land right. If it's in the right place at the right price, then it will sell. And it doesn't matter if they don't come back as a thousand others will be queuing up. But if you can make an extra $1 \%$ or $2 \%$ margin, surely you would want that? And what happens when supply and demand level out in one way or another?"

\section{'Inspired By You'}

What, then, is he doing in order to increase differentiation? The changes under way centre on the vision of selling a home rather than a house:

"The house purchase experience today is similar to the car purchase experience of 15 years ago. The car industry was waking up to the fact that there was a customer at the end of the process...We like to think of a strapline 'Inspired by you'. Though we haven't earned the place to say this externally yet."

A market research exercise confirmed the negative image of the industry as "a bunch of sharks", but equally showed clearly where potential for improvement lay, one consumer commenting that:

"If a house-builder could just take the stress out of the buying process, you would make a fortune."

To spread the word about what customers wanted, video clips summarising this 'voice of the customer' were played to hundreds of company staff in conferences.

The market research led to an eight-character segmentation of the market ${ }^{2}$. These stereotypes each a typical segment member, complete with name, picture, and profile - are used both internally to discuss communication and sales strategy, and externally in advertising to promote the notion that Bryant is about people not just bricks.

“These two, for example, don't have kids and are interested in city life. They are probably interested in a cheap entry point, so I can talk to them about paying $£ 99$ and they're in. Whereas this character, Maggie, who has kids, I can talk to about the supermarket and the new school on the development."

\footnotetext{
1 "Barratt" is a house building company allegedly reputed to be synonymous with modest specifications and quality

${ }^{2}$ See www.bryant.co.uk for examples of these stereotypes
} 
Following the market research, a multi-channel communications plan was developed, using different media - advertising, point of sale, sponsorship, digital, direct marketing - for different aspects of the customer relationship.

"Customers go through a journey with us of stranger, acquaintance, friend, know, like, love. Posters work well at the stranger level...Then when you're in a local paper, you might read a touch of detail. When you reach the web site - and well over half of our purchasers view it at some stage - you're beginning to be proactive."

Initial evaluation of the results of this multi-channel approach is positive, though suggesting some need for refinement:

"We ran some poster campaigns with just these two characters on, no houses, that's all. In the housing industry there were lots of questions about what we were up to...We need to fine-tune this, as we swung a bit too far in the direction of the characters for this stage of the relationship."

The customer-driven approach extends into the face-to-face phase of the relationship:

"We've looked at the marketing suites from a brand behaviours point of view. There's a current training programme just to get people to smile. The people we're selling to are so sophisticated - many being trained in marketing themselves - that they can see through it if the delivery isn't up to the promises made in the advertising."

Today's new house sales office is a bizarre experience: a temporary building in the midst of a morass of mud and machinery, with scarcely a house in sight, within which customers are advised to sign for the property they want, and dictated the necessary exchange date, before a brick has been laid. Trust was never so important nor in such short supply. Fortunately, at operational level the company seems to have a long-standing culture of caring about the customer in which customerdriven strategies that help to develop this trust are welcomed:

"We've got so many more tools available to us since Andy [the sales and marketing director] came in, and we're trying to use them more effectively. The end result is making Mr and Mrs Plot 25 so happy - that's what we're interested in. I want loyalty: If I can take that couple over there to 2.2 children on this development I'd be very happy. If our marketing campaign triples our visitor levels, we here can sell the houses.”

\section{From Transactions To Relationships}

Many of these changes can be summarised as being about simply becoming better transaction marketers. But other aspects of the quest for growth are about a transition from a transaction focus selling the houses which we build - to one based on lifetime value and a long-term relationship. Again, parallels with other industries are quoted by the drivers of change:

"If we're going to buy plane tickets from someone who used to sell us records, what might we buy from someone who sells us a house?"

“...why don't we regard ourselves as in the market of providing communities, not building houses?"

In order to sustain a longer-term relationship, some product/service innovation is needed: 
"You've got a three to five year gap before a repurchase. So the notion of sustaining a CRM programme seems tortuously impossible. However, if we extend into related services, like interior design, and utilities, and homecare, like a car warranty, then as well as adding revenue, it sustains the relationship."

While much of this vision is still on the drawing board, the notion of a continuing design service has already been launched, accounting for an already useful chunk of turnover. Termed Bryant Options, and controlled by a new design unit, it involves a special area within the sales office within which some personalisation of the new home can be achieved, as well as some additional services purchased later:

"This family here are being sold some extra design services - what they want their bathroom taps to look like, or their curtains. We might sell them a landscape garden later on. It allows people to make their house individual. Also it's a convenience thing - it saves them traipsing around shops at weekends looking at fabrics."

As many sites are multi-phase, the site office may be present for several years, but in due course, it is demolished and replaced by a final house. Where does this leave the vision of continuing services? The debate in the organisation on this point continues:

"Should we turn the sales office into a permanent community office that provides all the things that are so difficult to get - a plumber, a gardener, childcare? It depends on the metrics - it ties up capital."

As well as product innovation, communications perhaps have a role to play in sustaining the relationship. An occasional magazine for existing home-owners is under discussion, and again a contentious subject:

"It costs $£ 50$ per annum to maintain a relationship with customers - not that much, when you look at the cost of customer acquisition from scratch...People aged 30-40+ have moved seven or eight times...70\% of people say they'd like to move this year, whereas only $18 \%$ actually do. That's a huge latent demand - perhaps we can upsize some of those, or even downsize them if it keeps them within the community. But we're in the middle of the muck and bullet fight for resource."

Campaign-focused direct marketing is, though, less contentious, and has already been introduced as a 'quick win'. Much work has gone into tidying up the customer database to enable this. How about using this database as a basis for promotions-based loyalty programmes?

“There's scope for a loyalty programme of sorts. But we don't need to give away $£ 500$ off your next home. I'm not going to give away margin if it isn't needed. It's about taking the focus off price and on to the customer experience. Many brands do that now, and rightly so."

\section{Enabling Factors For Transitions}

\section{Board support}


The work of the sales and marketing director over the last two years has spanned two rather different boards. Initially, the board were sold on his vision of building the kind of brand that he had seen in previous roles in the car and financial services industries:

"I came to the organisation asking people to look through the other end of the telescope at what customers see of our organisation and what they would like to see. Look at places like Pret a Manger, Virgin, LandRover, and people are completely lined up behind the proposition and live the brand. The senior managers are passionate. So I know it can be done. Here, there's lots of latent enthusiasm. And there was already a customer 'change agent' stream, so there was something for me to grab hold of. We were making some progress up to last June, and then the momentum was lost in the reorganisation."

\section{The Role of Metrics}

The new board takes a more data-driven approach and challenges accordingly:

"In the past, Bryant was more driven by emotional levers - and by the views of the MD. There's been a change from opinion through to fact and key performance indicators...the debate is at a pretty basic stage again. Such as: demand exceeds supply so why do we need to make the customer feel good?"

In this environment, continued progress in this attempted 'transition to a relational model' is slowed, and dependent on clearing a series of budget hurdles:

"The second half-year budget is under the microscope as we speak. The core above-the-line spend is under debate."

Until metrics are in place which allow the board's concerns to be directly addressed, the discussion inevitably involves argument about the extent to which parallels with other industries hold.

"The issue we've got is that we can only build on the site we've got. So we might build in Warwick today but not build again there for decades. There's an issue of understanding the hierarchy of choice. If it's about location, we can't do a lot about that. Which reduces the attractiveness of the normal argument about retention being cheaper than acquisition."

Another senior manager is more prepared to act on intuitive judgements for the time being:

"I've been challenged as to why we should do any kind of CRM programme to keep in touch with our customers. The argument is that we don't need to worry about retaining customers. In my opinion that is an arrogant position to take...I'm currently having to base my argument on other industries, which opens me to the counter-argument that location and supply constraints make this industry different...we know from marketing in general that a referral is potent."

The debate about the relative costs of acquisition and retention is mirrored in board discussion of the impact of marketing communications on price: 
"Yes, it's difficult to quantify the effect on house prices of a better brand equity. But if you take the area around this head office, where Bryant started, we have more margin than anywhere else. There are several reasons. One is that we're a preferred customer for land sellers. And we're a preferred customer for service suppliers. And we're a preferred developer for agents. But also, because of the generally good customer reputation, we get a flag-to-flag premium3. So in this area we make more money. That's the brand in action."

Perhaps this debate, which appears to be about metrics, is also about underlying attitudes:

"If the underlying attitude is in the way, people will carry on asking for more numbers as a rationale for inaction."

"The fundamental challenge is to win hearts and minds internally. Otherwise it's like an unruly herd of sheep - you're forever wasting effort getting stragglers."

\section{Attitudinal Change}

If change involves hearts as well as minds, how has the transition been handled at lower levels of the organisation? The sales and marketing director feels his most successful work has been face to face:

"What really helped change hearts and minds originally was a series of conferences. The leadership team contributed on the stage, saying things to a hundred and eighty people that they probably weren't used to saying, and people certainly weren't used to hearing them say. As well as a central event, we had twelve regional events, hosted by the MD for that region, supported by the relevant board member. By delivering that event and witnessing the response from the floor which was invariably very positive, that really changed hearts and minds - of the leadership as well as the troops."

For the 'troops', a customers-first message did not involve too large a change in culture, given the company's traditional self-image as a high-quality, caring provider. But going beyond attitudes to behaviour nevertheless required some work:

"There are people within this business who really care about getting it right. The majority are very passionate, and do worry that we may be going back. What we didn't get an opportunity to do - because of the reorganisation - was put in place the reinforcement mechanisms, such as regular team sessions to think about how to translate the values into behaviours. Making marketing, sales and production people on site work in the same direction, for example."

Nevertheless, the 'troops' we interviewed were enthusiastic about the change that had already occurred:

"Andy and the agency coming on board has been very positive. Andy is interested in making sure that once you buy a Bryant home you never buy anything else, and quite rightly. We have more tools to use - it's very exciting for us...we're more into targeting, by segment and sometimes by individual."

\footnotetext{
${ }^{3}$ The term flag-to-flag refers to multi-developer sites where different builders are present on the same development. Characteristically each identifies their presence with a flag, hence competitors are "flag-to-flag" with each other.
} 


\section{The Relationship With Production And The Role Of Reward Systems}

The sales and marketing function has naturally been the most affected by the changes instituted by the sales and marketing director. But they cannot deliver happy customers without the cooperation of other parts of the business. A tension is evident between marketing's focus on customer satisfaction and the strong production driver of achieving planned completion dates:

"We make our money when we complete. Financial years have a nasty habit of coming round once a year. Whether it's intentional or not, the slippage that inevitably occurs through failing to get planning consent and so on results in compressing our building programmes, so quality tends to suffer."

This senior management view is reflected at the coalface:

"We're failing to deliver the dream at the moment, which upsets me greatly. We don't always deliver the product correctly and we don't always deliver on time."

"We measure customer satisfaction in the home owner's guide. The majority of the complaints are about quality of build."

"We get very good feedback on the customer's relationship with us, but that is in danger of being undone if the site manager is under excessive pressure to deliver on time."

If customer satisfaction drives referral and repurchase rates, it is clear that the sales and marketing director needs the help of his manufacturing peers in putting right these product quality issues. As one frustrated marketer put it:

"If we did what Siebel does and were given a bonus partly on revenue and partly on customer satisfaction, we'd be paying Taylor Woodrow. We can't even stop a brickie peeing in the toilet the day before handover."

How about incorporating customer satisfaction into the rewards of those who are in control of the brickies?

"That's being redressed...Many people in the organisation, actually, have a target for customer satisfaction which affects bonus."

The new commercial director, though, intended to use his production background to drive standards up in other ways too:

"We have a lever on design - getting the design right in the first place. And we need to ensure that the design is followed through in terms of delivery of the right materials at the right time, where we fall down...Now I can set procedures and standards for customer care and quality, and validate them."

\section{Consistency Over Time}

The company is attempting, then, to make some substantial and far-reaching changes to traditional practice in the industry: 
"There are two aspects to this transition. One is we're not listening to our customers, we're listening to the City. We need to do both. Secondly...it's about moving towards interaction marketing, part of which is database marketing...And that will help the City relationship too: the company allows the City to judge it by a manufacturing criterion of volume of output, which leads to massive undervaluing."

Given the scale of change, it is perhaps not surprising that the plan has to evolve to cope with changes in the external and internal environments:

"When the market changes, unless there's some suppleness, it'll snap off. So we need to keep our shape. So far we've achieved that."

Although experiencing difficult times, the agents of change show no signs of losing their passion for the task they have set themselves:

"Building a strong brand in this industry isn't easy - not least, delivering product consistency when the product is built outside in the English winter...At the same time, if you can get it right, you can mop up, because the standards are so low."

"It's definitely doable, otherwise I wouldn't be sat here...As long as I'm alive and kicking that will be the way I'm wired."

\section{ANALYSIS OF FINDINGS}

\section{The nature and detail of each marketing practice}

This exploratory case has led to a range of interim findings that provide the basis for further refinements as the research programme proceeds. The first research objective was to verify and enhance the CMP framework in Table 1, in particular those factors for which less substantial empirical support has so far been obtained. The findings of this case study would suggest that there is the opportunity to enhance and amend the framework. Firstly, Table 2 was generated to summarise how the case study data matches against the dimensions of practice of Table 1.

\section{[Insert Table 2 about here]}

This led to the generation of Table 3, in which the italicised entries represent suggestions as to how the original table (Coviello et al 2002) can be enhanced as a result of the case study.

\section{[Insert Table 3 about here]}

Comparing Tables 3 and 1, and firstly considering transaction marketing, it can be seen that whilst this is of a "one to many" nature, it is not necessarily an impersonal and remote activity as Coviello et al (2002) had suggested. This case suggests that even with a transactional approach, actors may express commitment and may be involved and concerned as to the well-being of the 
customer as well as being committed to achieving a successful transaction for the company, while even mass media communications may be perceived as somewhat personal by the recipient through such techniques as segmentation. This personal contact can be distinguished from the marketing activity itself which is task oriented and designed to develop and manage the customer contact on a behavioural basis through to a successful conclusion. In this circumstance the strategic emphasis is on management of the elements of the marketing mix - posters, local press advertising, website design etc - rather than through a relational orientation. With the goal being the completion of the sale, the duration of contact is within the timeframe required to achieve that sale, with contact being managed with that objective in mind; but as this case suggests, a complex transaction may involve fairly continuous contact even within that limited timeframe. Repeat transactions may be irrespective of previous transactions, particularly if there is little commitment to managing the relationship by means of CRM activities. This distinguishes the relationship as being transactional, as without interim contact or pro-active management of the relationship between transactions this could not be considered spasmodic or episodic, in the sense that the term is used within an interaction model (Ford 1997). The formality of the exchange is hence derived from the underlying driver of the sales process and completion of the sale, but within that personal relationships between actors can be positive and demonstrate commitment.

Table 3 also suggests some modifications to the characterisation of database marketing, of which the case shows increasing aspects. The use of perhaps quite modest technology, a simple stand alone database application for example, enables personalisation of communication and the opportunity for better management of the transaction over the buying cycle. However this is behavioural rather than attitudinal in terms of personalisation. Unless carefully managed there is the risk that this can appear either incompetent or insincere to the detriment of the relationship. Nevertheless, database marketing even if competently executed is inherently likely to be taskfocused rather than focused on the wider relationship.

By contrast, interaction marketing is based on inter-personal relationships and an attitudinal orientation based on mutual trust and commitment. However, the moves within this case towards an interaction marketing approach demonstrate that, contrary to Coviello et al (2002) who listed the nature of communication as 'Individuals with individuals', an interactive relationship need not necessarily be built by a specific individual within the selling organisation. Rather, various individuals and indeed systems may interact with an individual customer, coordinating with each other directly or through shared IT systems. Neither need this contact be face-to-face for it to be interactive and feel personalised. Furthermore, there is no evidence from this case that an interaction marketing approach necessarily involves social as well as business contact: perhaps this assumption by Coviello et al (2002) is another of the misconceptions that arises from the association of relationship marketing particularly with the business-to-business sphere. 
Taken collectively, these changes at a detailed level, if confirmed, would suggest that changes would be necessary to the definitions of the marketing practices. Proposed redefinitions are shown in table 4.

\section{[Insert Table 4 about here]}

The definition most clearly affected by the hypothesised changes to the dimensions of practice table is that for interaction marketing. This has been reworded to emphasise individualisation of the relationship via interaction, which this case has shown may or may not be enabled by individual interpersonal relationships.

The other definitions similarly separate the issue of the nature of the relationship from the medium through which the relationship is conducted. So database marketing is defined not in terms of the technology used but in terms of the targeted, primarily uni-directional (supplier to customer) nature of the communications. (To fit this redefinition, a suggested retitling of 'targeted marketing' is proposed.) And while the original definition of transaction marketing could still be used, an alternative is suggested which centres on the broadcast nature of marketing communications and the transactional nature of the sales process.

It logically follows that e-marketing is not a marketing archetype, as has been proposed by Coviello et al (2001), but is rather simply one medium that may be used in any of the archetypes, lending support to the argument of Brady et al (2002). To take some parallels from other industries, EasyJet is a transaction e-marketer; Tesco and McKinsey Quarterly are database e-marketers; Dell and IBM are interaction e-marketers; and via the private e-marketplaces that have replaced the pioneering but now defunct e-hub Covisint, Ford and General Motors are network e-purchasers and their tier one suppliers are network e-marketers.

These redefinitions could form propositions to be tested in further case work.

\section{Drivers and enablers of transitions between marketing practices}

Our second and third research objectives deal with the issue of transition between practices. This is an important topic for the case study company, as the envisaged business model is based on customer retention and management of the income stream from a customer over time, yet the parent business is traditionally strongly transactional in focus. While the company concurrently practices several marketing archetypes, it has been making strenuous efforts to increase the representation of interaction and database marketing within its mix of practices, with the consequent opportunity to enrich the understanding of the issue of transitions.

The drivers of change in this case are summarised in Table 5. An important component of the argument for change in the company is the vision of enhancing revenue in the longer term and margins in the more immediate future, via service enhancement such as the design service and better brand differentiation. When "flag-to-flag", the interviewees demonstrated their intuitive belief that such increased margins were achievable by such means. An increased market 
understanding and the use of segmentation also gave confidence that a different marketing approach held promise for the future. This was reflected in the comments of front line sales staff but it was clear that this vision was not universally shared in the organisation, which brings us to the issue of enabling and inhibiting factors.

\section{[Insert Table 5 about here]}

Factors affecting the successful adoption of new marketing practices arising from this case are listed in Table 6. These relate to top team buy-in, operational buy-in, alignment with reward systems, the development of a metrics set appropriate to the desired marketing practice and the need for long-term commitment to the transition balanced by supple planning to accommodate the practicalities implied.

\section{[Insert Table 6 about here]}

The need for buy-in at top team and operational level is common to many studies of business change such as CRM projects (Ryals et al 2000; Wilson et al 2002) and IT system introduction (Leverick et al 1998), though the uncertainties involved in such a fundamental change mean that in this case at least, top team buy-in is a matter of hearts as well as minds. The other factors are similarly reflections of the deep-running nature of a change in marketing practice. The metrics by which the business is controlled may implicitly suggest a particular marketing practice, so these may need to be modified. Similarly, reward systems for a transactional and an interaction approach, for example, may need to be very different. Furthermore, the nature of the transition may be of such complexity that a single, classically managed project is probably an unrealistic model. In this case at least, the transition has more of the feel of a long-term objective encapsulating various specific projects along the way.

It is clear that further cases are desirable to explore whether these hypothesised drivers and enabling factors are common to other transition programmes, and what further factors prove relevant.

\section{CONCLUSIONS}

The Contemporary Marketing Practice stream of research lends a valuable precision to thinking about relationship marketing, transaction marketing and other marketing practices, but its emphasis to date on quantitative methods has its limitations. Through this case study we have begun to address some of these, notably:

1. Previous survey work suggested that the CMP researchers' key model of table 1 had some weaknesses. The case study has led to some proposed amendments to this table which embody some significant shifts in our understanding of what marketers actually do. For 
example, transaction marketing need not necessarily feel impersonal or formal, though it is likely to have a higher degree of task focus than interaction marketing.

2. These amendments lead to some suggested redefinitions to the list of marketing practices or archetypes in Table 4. Notably, these redefinitions separate the issue of the medium from that of the marketing archetype. So database marketing is replaced by targeted marketing; e-marketing is removed from the list of marketing archetypes; and interaction marketing is characterised by interaction and individualisation in the relationship rather than specifically by person-to-person contact.

3. An important issue for practitioners is how transitions are made between marketing practices. We have inductively proposed various drivers and enabling factors (in tables 5 and 6), which need validating and refining in further research.

A further output of this study is the case study protocol as refined in the light of experience with the case. An important interim conclusion is that the approach appears promising in addressing the research objectives. Whilst we acknowledge the severe limitations of drawing conclusions based on a single case study, the findings give us confidence to proceed with further detailed case studies using the protocol developed through the medium of this initial case, and we would encourage other researchers to do likewise, leading to the possibility of multiple-case analysis (Yin 1994; Manning 1982; Wilson et al 2002). Whilst the argument as to how many cases constitute a sufficient number for confidence in the conclusions continues, a single case is clearly insufficient.

The recent emphasis on relationship marketing has set out an alternative vision of marketing practice. The emphasis of the CMP research tradition on what marketers actually do within this and other archetypes helps to translate this vision into a coherent design for each marketing archetype, while its neutral perspective on what constitutes the most appropriate marketing practice (or set of practices) for an individual company acknowledges the limitations of knowledge in the field. We believe that studies such as this are needed to add further detail and refinement to these designs so that, once marketers have chosen which archetype is most appropriate for them, they can start to construct or change their marketing practice with more confidence.

\section{REFERENCES}

Blattberg, R.C. and Deighton, J. (1996), "Managing Marketing by the Customer Equity Criterion", Harvard Business Review, Vol. 74, pp.136-44

Bonoma, T. (1984), "Making Your Marketing Strategy Work", Harvard Business Review, Mar-Apr, pp. 69-76

Brady, M., Saran, M. and Tzokas, N. (2002), "Integrating Information Technology into Marketing Practice - The IT Reality of Contemporary Marketing Practice", Journal of Marketing Management, Vol. 18, pp.555-577.

Brodie, R., Coviello, N., Pels, J., and Gronroos, C. (2001), "Profiling Contemporary Marketing Practice: Cross National Comparisons". In: EMAC 2001, Bergen, Norway, http://euro.nhh.no/emac/ 
Brodie, R.J., N.E. Coviello, R.W. Brookes and V. Little (1997), "Towards a Paradigm Shift in Marketing? An Examination of Current Marketing Practices", Journal of Marketing Management, Vol. 13 No. 5, pp. 383-406

Brookes, R.W., Palmer, R.A. (2004), The New Global Marketing Reality, Basingstoke, Palgrave

Brownlie, D., and Saren, M. (1997), "Beyond the one dimensional marketing manager", International Journal of Research in Marketing, Vol. 28 No.3, pp.6-12

Brownlie, D., Saren, M., Wensley, R., and Whittington, R. (1999), "Marketing disequilibrium: on redress and restoration”. In: Brownlie, D., Saren, M., Wensley, R., and Whittington, R., (Eds), Rethinking Marketing, Toward Critical Marketing_Accountings, Sage, London, pp. 1-22

Coviello, N., Milley, R. and Marcolin, B. (2001), "Understanding IT-enabled Interactivity in Contemporary Marketing”, Journal of Interactive Marketing, Vol. 15, No.4, pp.18-33.

Coviello, N.E., Brodie, R.J., Danaher, P.J., and W. Johnston (2002), "How Firms Relate to Their Markets: An Empirical Examination of Contemporary Marketing Practices", Journal of Marketing, Vol. 66 No.3, pp. 33-46.

Coviello, N.E., R.J. Brodie and H.J. Munro (1997), "Understanding Contemporary Marketing: Development of a Classification Scheme", Journal of Marketing Management, Vol. 13 No.6, pp. 501-522.

Ford, D (1997), Understanding Business Markets, Oxford, Dryden Press

Hunt, S. D. (1976), "The nature and scope of marketing", Journal of Marketing, Vol. 40, pp. 17-28

Jick, T.D.(1979), "Mixing Qualitative and Quantitative Methods: Triangulation in Action", Administrative Science Quarterly, Vol. 24, pp. 602-610

Leverick, F., Littler, D, Bruce, M and Wilson, D (1998), "Using Information Technology Effectively: A Study of Marketing Installations", Journal of Marketing Management, Vol. 14, pp. 927-962

Miles, M.B., Huberman, A.M. (1994), Qualitative Data Analysis, London, Sage

Manning, P. (1982), “Analytic induction". In: Qualitative methods: A handbook of social science methods, Vol 2, R. Smith and P. Manning (eds.), pp. 273-302, Ballinger, Cambridge, MA.

Murray, J.A., O'Driscoll, A, Torres, A. (2002), "Discovering Diversity in Marketing Practice", European Journal of Marketing, Vol. 36 No. 3, pp. 373-390.

Reichheld, F. (1996). The Loyalty Effect, Boston, MA, Harvard Business School Press.

Reichheld, F. and Sasser, W.E. Jr. (1990), “Zero Defections: Quality Comes to Services”, Harvard Business Review, Vol. 68 (Sept-Oct), pp. 105-11.

Ryals, L., Knox, S. and Maklan, S. (2000), Customer relationship management (CRM): building the business case, FT Prentice Hall, London.

Sheth, J. N. (2000), "Relationship Marketing: Paradigm Shift or Shaft ?'. In: J. N. Sheth and A.Parvatiyar (eds.), Handbook of Relationship Marketing, Thousand Oaks, Ca, Sage, pp.609620

Webster, F.E. (1992), “The Changing Role of Marketing in the Corporation”, Journal of Marketing, Vol. 56, pp.1-17.

Wilson, H., Daniel, E.M and McDonald, M.H.B. (2002), "Factors for success in customer relationship management (CRM) systems", Journal of Marketing Management, Vol. 18 No. 1-2, pp.193-220

Yin, R.K. (1994), Case Study Research - Design and Methods, London, Sage 
Table 1: Practices classified by exchange and managerial dimensions (Coviello et al 2002)

\begin{tabular}{|c|c|c|c|c|}
\hline & Transaction marketing & Database marketing & Interaction marketing & Network marketing \\
\hline Purpose of exchange & Economic transaction & $\begin{array}{l}\text { Information and economic } \\
\text { transaction }\end{array}$ & $\begin{array}{l}\text { Interactive relationships } \\
\text { between a buyer and seller }\end{array}$ & $\begin{array}{l}\text { Connected relationships } \\
\text { between firms }\end{array}$ \\
\hline Nature of communication & Firm to mass market & $\begin{array}{l}\text { Firm to targeted segment or } \\
\text { individuals }\end{array}$ & $\begin{array}{l}\text { Individuals with individuals } \\
\text { (across organisations) }\end{array}$ & $\begin{array}{l}\text { Firms with firms (involving } \\
\text { individuals) }\end{array}$ \\
\hline Type of contact & Arm's-length, impersonal & Personalized (yet distant) & $\begin{array}{l}\text { Face-to-face, interpersonal } \\
\text { (close; based on commitment, } \\
\text { trust and cooperation) }\end{array}$ & $\begin{array}{l}\text { Impersonal to interpersonal } \\
\text { (ranging from distant to close) }\end{array}$ \\
\hline Duration of exchange & Discrete (yet perhaps over time) & Discrete and over time & $\begin{array}{l}\text { Continuous (ongoing and } \\
\text { mutually adaptive, may be short } \\
\text { or long term) }\end{array}$ & $\begin{array}{l}\text { Continuous (stable yet dynamic, } \\
\text { may be short or long term) }\end{array}$ \\
\hline Formality in exchange & Formal & $\begin{array}{l}\text { Formal (yet personalized } \\
\text { through technology) }\end{array}$ & $\begin{array}{l}\text { Formal and informal (ie both at } \\
\text { a business and social level) }\end{array}$ & $\begin{array}{l}\text { Formal and informal (ie both at } \\
\text { a business \& social level) }\end{array}$ \\
\hline Managerial intent & $\begin{array}{l}\text { Customer attraction (to satisfy } \\
\text { the customer at a profit) }\end{array}$ & $\begin{array}{l}\text { Customer retention (to satisfy } \\
\text { the customer, increase profit, } \\
\text { and attain other objectives such } \\
\text { as increased loyalty, decreased } \\
\text { customer risk and so forth) }\end{array}$ & $\begin{array}{l}\text { Interaction (to establish, } \\
\text { develop, and facilitate a } \\
\text { cooperative relationship for } \\
\text { mutual benefit) }\end{array}$ & $\begin{array}{l}\text { Coordination (interaction } \\
\text { among sellers, buyers, and other } \\
\text { parties across multiple firms for } \\
\text { mutual benefit, resource } \\
\text { exchange, market access, and so } \\
\text { forth) }\end{array}$ \\
\hline Managerial focus & Product or brand & $\begin{array}{l}\text { Product/brand and customers (in } \\
\text { a targeted market) }\end{array}$ & $\begin{array}{l}\text { Relationships between } \\
\text { individuals }\end{array}$ & $\begin{array}{l}\text { Connected relationships } \\
\text { between firms (in a network) }\end{array}$ \\
\hline Managerial investment & $\begin{array}{l}\text { Internal marketing assets } \\
\text { (focusing on product/service, } \\
\text { price, distribution, promotion } \\
\text { capabilities) }\end{array}$ & $\begin{array}{l}\text { Internal marketing assets } \\
\text { (emphasising communication, } \\
\text { information, and technology } \\
\text { capabilities) }\end{array}$ & $\begin{array}{l}\text { External market assets (focusing } \\
\text { on establishing and developing } \\
\text { a relationship with another } \\
\text { individual) }\end{array}$ & $\begin{array}{l}\text { External market assets (focusing } \\
\text { on developing the firm's } \\
\text { position in a network of firms) }\end{array}$ \\
\hline Managerial level & $\begin{array}{l}\text { Functional marketers (eg sales } \\
\text { manager, product development } \\
\text { manager) }\end{array}$ & $\begin{array}{l}\text { Specialist marketers (eg } \\
\text { customer service manager, } \\
\text { loyalty manager) }\end{array}$ & $\begin{array}{l}\text { Managers from across functions } \\
\text { and levels in the firm }\end{array}$ & General manager \\
\hline
\end{tabular}

Key:italics indicate hypotheses we have questioned due to data presented by Coviello et al (2002) 


\section{Table 2}

Taylor Woodrow and the dimensions of marketing practice

\begin{tabular}{|c|c|c|}
\hline & Taylor Woodrow & Notes \\
\hline Purpose of exchange & $\begin{array}{l}\text { Economic transaction, with move } \\
\text { towards information acquisition }\end{array}$ & $\begin{array}{l}\text { A transition is in progress towards gaining } \\
\text { information to support relationship }\end{array}$ \\
\hline $\begin{array}{l}\text { Nature of } \\
\text { communication }\end{array}$ & $\begin{array}{l}\text { Firm to mass market, plus individual } \\
\text { selling and service }\end{array}$ & $\begin{array}{l}\text { Unlike FMCG companies, media } \\
\text { communications are followed by individual } \\
\text { selling }\end{array}$ \\
\hline Type of contact & $\begin{array}{l}\text { Arm's-length though with a personal } \\
\text { feel, then face-to-face and personal }\end{array}$ & $\begin{array}{l}\text { From the start, media comms are segment- } \\
\text { specific and are looking to establish a } \\
\text { relationship, so even remote contacts are not } \\
\text { believed to be 'arms-length' }\end{array}$ \\
\hline Duration of exchange & $\begin{array}{l}\text { A single purchase cycle which takes } \\
\text { some months. Moves to extend to } \\
\text { longer-term relationship }\end{array}$ & $\begin{array}{l}\text { The relationship was described as 'continuous } \\
\text { till purchase. We are looking to extend this post- } \\
\text { purchase.' }\end{array}$ \\
\hline Formality in exchange & $\begin{array}{l}\text { Business rather than social, with some } \\
\text { personalisation through technology } \\
\text { and human contact }\end{array}$ & $\begin{array}{l}\text { The word 'formal' doesn't fit how the exchange } \\
\text { is regarded, but neither does it extend to the } \\
\text { social plane. }\end{array}$ \\
\hline Managerial intent & $\begin{array}{l}\text { Customer attraction, with move to } \\
\text { cooperative relationships }\end{array}$ & $\begin{array}{l}\text { A transition is being attempted to a relationship } \\
\text { based intent }\end{array}$ \\
\hline Managerial focus & Product/brand and segments & $\begin{array}{l}\text { Execution includes the individual level, but } \\
\text { planning is at the segment level }\end{array}$ \\
\hline Managerial investment & $\begin{array}{l}\text { Primarily 4Ps focused, with some } \\
\text { investment in technologies to support } \\
\text { relationships }\end{array}$ & $\begin{array}{l}\text { The appropriateness of investing in individual } \\
\text { relationships is still under debate at board level }\end{array}$ \\
\hline Managerial level & Functional and specialist marketers & $\begin{array}{l}\text { Other managers are assessed partly on customer } \\
\text { satisfaction }\end{array}$ \\
\hline
\end{tabular}

Table 3

Hypothesised amendments to CMP framework generated by initial case study

\begin{tabular}{|c|c|c|c|}
\hline & Transaction marketing & Database marketing & Interaction marketing \\
\hline $\begin{array}{l}\text { Nature of } \\
\text { communication }\end{array}$ & Firm to mass market & $\begin{array}{l}\text { Firm to targeted segment or } \\
\text { individuals }\end{array}$ & With individuals, two-way \\
\hline Type of contact & $\begin{array}{l}\text { One-to-many media } \\
\text { communications; sales process } \\
\text { focusing mainly on task rather } \\
\text { than people (where sale is not } \\
\text { handled by, eg, a channel) }\end{array}$ & Personalised (yet distant) & $\begin{array}{l}\text { Highly interactive; generally } \\
\text { interpersonal, though can be } \\
\text { intermediated by technology } \\
\text { (close; based on commitment, } \\
\text { trust and cooperation) }\end{array}$ \\
\hline $\begin{array}{l}\text { Duration of } \\
\text { exchange }\end{array}$ & $\begin{array}{l}\text { For duration of transaction } \\
\text { (yet may be over time with } \\
\text { repeat transactions) }\end{array}$ & $\begin{array}{l}\text { Occasional, perhaps with } \\
\text { intensive periods of } \\
\text { customer contact }\end{array}$ & $\begin{array}{l}\text { Continuous (ongoing and } \\
\text { mutually adaptive, may be short } \\
\text { or long term) }\end{array}$ \\
\hline $\begin{array}{l}\text { Formality in } \\
\text { exchange }\end{array}$ & $\begin{array}{l}\text { Primarily task-focused,with } \\
\text { medium to high formality }\end{array}$ & $\begin{array}{l}\text { Formal, task-focused (yet } \\
\text { personalised through } \\
\text { technology) }\end{array}$ & $\begin{array}{l}\text { Focused on wider relationship } \\
\text { so includes deeper listening } \\
\text { (may include informal) }\end{array}$ \\
\hline
\end{tabular}

Key: italics indicate proposed changes from CMP framework of Table 1 


\section{Table 4}

\section{Suggested redefinitions of marketing practices or archetypes}

\begin{tabular}{|c|c|c|}
\hline $\begin{array}{l}\text { Marketing } \\
\text { Archetype }\end{array}$ & Previous definition* & Suggested redefinition \\
\hline $\begin{array}{l}\text { Transaction } \\
\text { marketing }\end{array}$ & $\begin{array}{l}\text { Managing the marketing mix to } \\
\text { attract and satisfy customers }\end{array}$ & $\begin{array}{l}\text { Attracting customers through mass media, and } \\
\text { serving them through a series of transactions } \\
\text { without significant tailoring of the product/service } \\
\text { on the basis of accumulated customer } \\
\text { information }\end{array}$ \\
\hline $\begin{array}{l}\text { Database } \\
\text { marketing }\end{array}$ & $\begin{array}{l}\text { Using technology-based tools to } \\
\text { target and retain customers }\end{array}$ & $\begin{array}{l}\text { Targeted marketing: Using accumulated } \\
\text { customer information to promote to prospects } \\
\text { and existing customers, primarily through uni- } \\
\text { directional communications followed by simple } \\
\text { transactions; tailoring of comms and/or } \\
\text { product/service at most at segment level }\end{array}$ \\
\hline $\begin{array}{l}\text { Interaction } \\
\text { marketing }\end{array}$ & $\begin{array}{l}\text { Developing interpersonal } \\
\text { relationships between individual } \\
\text { customers and sellers }\end{array}$ & $\begin{array}{l}\text { Developing individualised relationships betweeen } \\
\text { the organisation and its customers, built through } \\
\text { interactive communications sustained over time }\end{array}$ \\
\hline $\begin{array}{l}\text { Network } \\
\text { marketing }\end{array}$ & $\begin{array}{l}\text { Positioning the firm in a connected } \\
\text { set of inter-firm relationships }\end{array}$ & $\begin{array}{l}\text { Positioning the firm in a connected set of inter- } \\
\text { firm relationships }\end{array}$ \\
\hline E-marketing & $\begin{array}{l}\text { Using the Internet and other } \\
\text { interactive technologies to create } \\
\text { and mediate dialogue between the } \\
\text { firm and identified customers }\end{array}$ & (Not an archetype) \\
\hline
\end{tabular}

Table 5

Drivers of transitions between marketing practices

\begin{tabular}{|l|l|l|}
\hline Driver & Proposition & Illustrative quotations \\
\hline Market maturity & $\begin{array}{l}\text { One competitive response to market maturity can } \\
\text { be to look for additional value via a transition from } \\
\text { transaction marketing to database and interaction } \\
\text { marketing, hence adding service and/or } \\
\text { individualisation elements to support the better- } \\
\text { understood customer need. }\end{array}$ & $\begin{array}{l}\text { "We've looked at the planning } \\
\text { environment and found that our } \\
\text { ability to differentiate ourself on } \\
\text { product is increasingly difficult." }\end{array}$ \\
\hline $\begin{array}{l}\text { Constraints on volume } \\
\text { growth }\end{array}$ & $\begin{array}{l}\text { Where growth in customer numbers is constrained } \\
\text { due to legislation, capacity or otherwise, corporate } \\
\text { objectives may best be satisfied through a transition } \\
\text { to database and/or interaction marketing to increase } \\
\text { margin and share of wallet }\end{array}$ & $\begin{array}{l}\text { "Buying the best locations is } \\
\text { increasingly difficult. So we've said } \\
\text { let's look at other elements of the } \\
\text { mix, which are really around } \\
\text { customer service." }\end{array}$ \\
\hline Executive team changes & $\begin{array}{l}\text { Senior marketing executives or CEOs may have a } \\
\text { predisposition towards particular archetypes, } \\
\text { resulting in an attempted transition on their } \\
\text { appointment }\end{array}$ & $\begin{array}{l}\text { "As long as I'm alive and kicking, } \\
\text { that will be the way I'm wired" }\end{array}$ \\
\hline
\end{tabular}




\section{Table 6}

\section{Enabling factors for transitions between marketing practices}

\begin{tabular}{|c|c|c|}
\hline Enabling factor & Proposition & Illustrative quotations \\
\hline Top team buy-in & $\begin{array}{l}\text { A transition in archetype is such a } \\
\text { fundamental and far-reaching change } \\
\text { that it will prove impossible to justify } \\
\text { it entirely through project-by-project } \\
\text { financial cases, due to the difficulty } \\
\text { in assembling data. It therefore will } \\
\text { not work unless the senior } \\
\text { management team believe in the } \\
\text { desirability of the transition for } \\
\text { broader rational or emotional } \\
\text { reasons. A switch to interaction or } \\
\text { network marketing needs particularly } \\
\text { broad support. }\end{array}$ & $\begin{array}{l}\text { Views from a more sceptical board member: "No- } \\
\text { one disagrees with the blue-sky vision. The issue is } \\
\text { how you get there..If you look at the cost of } \\
\text { maintaining relationships, there are questions as to } \\
\text { whether we do have the data." "Andy and his team } \\
\text { are using a different approach to other } \\
\text { housebuilders from a communications point of } \\
\text { view. Now is that a major transition?" } \\
\text { Cf views of driver: } \\
\text { "The argument is that we don't need to worry about } \\
\text { retaining customers. In my view that's completely } \\
\text { arrogant. But when you start from scratch, with a } \\
\text { weak database, it's going to take a while to build up } \\
\text { that story...So I'm currently having to base my } \\
\text { argument on other industries" }\end{array}$ \\
\hline Operational buy-in & $\begin{array}{l}\text { Commitment to a transition at } \\
\text { operational level is aided by a } \\
\text { consistent senior management } \\
\text { message, backed up by appropriate } \\
\text { changes to processes. The transition } \\
\text { will be easier if it can draw on latent } \\
\text { attitudes }\end{array}$ & $\begin{array}{l}\text { "There's lots of latent enthusiasm." "What we } \\
\text { didn't do enough of last year is work on managers } \\
\text { walking the talk." Marketing exec: "Andy and the } \\
\text { new agency coming on board has been very } \\
\text { positive. We have more tools to use." But more } \\
\text { recently, "we've all been through a lot of upheaval, } \\
\text { and the communication has been extremely poor" }\end{array}$ \\
\hline $\begin{array}{l}\text { Alignment with reward } \\
\text { systems }\end{array}$ & $\begin{array}{l}\text { Reward systems need to be aligned } \\
\text { with the new archetype combination. }\end{array}$ & $\begin{array}{l}\text { Coalface comment: "We're failing to deliver the } \\
\text { dream at the moment, which upsets me greatly..If } \\
\text { we did what Siebel does and were given a bonus } \\
\text { partly on revenue and partly on customer } \\
\text { satisfaction, we'd be paying Taylor Woodrow." }\end{array}$ \\
\hline $\begin{array}{l}\text { Development of metrics } \\
\text { appropriate to archetype }\end{array}$ & $\begin{array}{l}\text { After a transition, a different metrics } \\
\text { set will be needed for running the } \\
\text { business, such as retention and CLV } \\
\text { metrics in the case of database and } \\
\text { interaction marketing. This needs to } \\
\text { be worked towards, while allowing } \\
\text { rough estimates in the meantime }\end{array}$ & $\begin{array}{l}\text { "I'm trying to get them to think what other } \\
\text { industries have done to become more successful - } \\
\text { its not just about initial purchase price, its about a } \\
\text { greater share of purse and a long time value } \\
\text { customer." }\end{array}$ \\
\hline $\begin{array}{l}\text { Long-term } \\
\text { commitment, supple } \\
\text { planning }\end{array}$ & $\begin{array}{l}\text { A transition between archetypes is } \\
\text { likely to require sustained } \\
\text { commitment over a substantial } \\
\text { period. The plan will therefore need } \\
\text { flexibility to cope with changes in the } \\
\text { company or its market in the } \\
\text { meantime. }\end{array}$ & $\begin{array}{l}\text { "When the market changes, unless there's some } \\
\text { suppleness, it'll snap off." }\end{array}$ \\
\hline
\end{tabular}

